\title{
Sem palavra inspirada não há movimento: lições mbya de escuta e fala
}

\author{
ALINE DE OLIVEIRA ARANHA \\ UNIVERSIDADE DE SÃO PAULO (USP), SÃO PAULO/SP, BRASIL \\ HTTPS://ORCID.ORG/0000-0002-I422-384I
}

\begin{abstract}
Abertura
O título deste ensaio ${ }^{1}$ se inspira na referência ao princípio guarani belamente enunciado por Bartomeu Meliá, sem palavra mítica, não há movimento (apud Ladeira 2007 [1992]: 13), e parte de uma proposta de análise da potência da palavra (que também é nome-espírito-caminho) entre @ $\mathrm{s}^{2}$ Guarani Mbya e sua capacidade de provocar moviment(ações), passando por uma discussão da relação entre linguagem, política e gênero e suas estratégias na produção-proteção de sujeitos e mundos. Busco aqui também contribuir para a valorização da importância dos saberes, práticas e perspectivas das kunhãgue ("mulheres"),
\end{abstract}

1 É também um desdobramento de umas das ideias desenvolvidas em minha Dissertação de Mestrado, apoiada pela FAPESP, que parte de minha experiência de campo e caminhada junto aos Guarani, desde 2012, sobretudo entre as lideranças (-uvixa kuery) da Terra Indígena (T.I.) Tenonde Porã - localizada entre o extremo sul do município de São Paulo e o litoral -, em diálogo direto com uma proposta de revisão da literatura guaranióloga. Este trabalho contou ainda com o apoio do Projeto Diplomacias Cosmopoliticas nas terras baixas sul-americanas coordenado pelo Prof. Dr. Renato Sztutman (USP), financiado também pela FAPESP. Agradeço aqui, especialmente ao Renato, pela leitura e generosidade, mas também pela força e incentivo fundamentais no percurso de amadurecimento dessa pesquisa e, em minha formação enquanto etnóloga.

2 O uso do “@” ao longo do texto serve, como justificado em minha Dissertação, para expressar um englobamento entre as letras "a” e “o”, fazendo aparecer a relação de complementaridade entre os gêneros e o duplo sentido do gênero d@ polític@ entre @s Guarani: do fazer política entre tant@s outr@s e do fazer político entre si; e, do fazer-se política ou político em todos os planos, por meio da mobilização relacional que cada pessoa (que contêm em si muit@s outr@s), "independente do gênero" - como traduziu uma de minhas grandes interlocutoras, Jera Poty Mirĩ (T.I. Tenonde Porã [SP] 2015) -, se dispõe a realizar (ver Aranha 2018). 
levando a sério o que dizem e fazem, abrindo espaço e visibilidade para sua agência cosmopolítica ${ }^{3}$, especialmente às suas palavras inspiradas, fazendo-as aparecer de fato na dinâmica cosmopolítica guarani. Oferecendo assim, um contraste a uma certa literatura guaranióloga que acaba por concentrar grande parte da administração e circulação dos saberes-poderes inspirados pelas divindades e, comum a tod@s Mbya, apenas na figura masculina dos chefes e dos xamãs, interlocutores aí privilegiados, dispensando atenção, muitas vezes, na descrição etnográfica ${ }^{4}$, para a importância, valor e centralidade das mulheres no sistema xamânico guarani e na produção, proteção, gestão e mobilização de pessoas e relações.

Para tanto, busco me inspirar, principalmente, nos estudos de gênero contemporâneos empreendidos por antropólogas atentas à importância das mulheres indígenas e em uma perspectiva que não necessariamente visualiza as relações de gênero na chave da “dominação masculina” (Overing 1986, Strathern 2006 [1988], 2014 [1984], Franchetto 1996, Lasmar 1999, Belaunde 2006, McCallum 2013, entre tantas outras) e também por guaraniólogas que reconhecem e apontam, de algum modo, a liderança e orientação xamânica das kunhãgue tanto nos movimentos migratórios como na dinâmica de produção-proteção dos tekoa $a^{5}$ (Ciccarone 2001, 2004, Ladeira 2007 [1992], Mello 2006, Pissolato 2007, 2012, Macedo 2010, Prates 2013, Ramo 2014, Testa 2014). Nessas movimentações desempenhadas pelos diversos sujeitos em suas experiências de comunicação e negociação entre seres, poderes e mundos, que demandam diferentes ações e retóricas de acordo com cada contexto, penso ser possível visualizar a mobilização de capacidades singulares de agir, fazer agir, afetar e ser afetad@, das disposiçôes cosmopolíticas relacionais-diferenciantes de cada gênero em ação.

É importante ressaltar que a intenção de partir de uma perspectiva não androcêntrica ${ }^{6}$ da diplomacia cosmopolítica e do xamanismo guarani, além de possibilitar a abertura a um outro olhar na descrição

3 Uma proposta analítica inicialmente formulada por Isabelle Stengers e desdobrada por Bruno Latour no âmbito dos science studies que, antes de tudo, faz um esforço de repensar e desestabilizar o que entendemos por política, dessa tentativa de estabelecer um mundo comum e estável enquanto se prolifera um pluralismo ontológico, advogando então a favor dessa multiplicidade e contra sua unificação, compreendendo a política como a arte de compor mundos (ver Sztutman 2012, 2017). Essa noção é apropriada e renovada por etnólog@s americanistas em busca de unir o que não é separado nas socialidades ameríndias, a política e o cosmos, passando a compreender a diplomacia cósmica, o tal relacionalismo generalizado, essa negociação constante entre os diversos seres-poderes do cosmos, como algo em incessante movimento e em processo de (des)construção. Seria nessa diplomacia cosmopolítica, feita na mediação e composição entre sujeitos e mundos, humanos e não-humanos, que cada corpo e gênero se individua, fabricando sua "roupa" e disposições específicas (ver Viveiros de Castro 2002). Não se trata, contudo, segundo Sztutman (2015), de reduzir o termo ao problema da política dos outros ou a uma etnopolitica, como se a verdadeira política fosse algo exclusivo ao mundo ocidental, ou como se não fôssemos também étnicos, uma vez que definimos política por meio de uma ontologia, um cosmos sempreparticular.

4 Ao ressaltar tal perspectiva privilegiada nas descrições e análises, independente do gênero dxs autorxs, não queremos aqui, de nenhum modo, desvalorizar suas contribuições ou mesmo deixar de levar em consideração, que a sua adoção pode também depender de modos ou recortes relacionais específicos estabelecidos em campo, ou mesmo anteriormente às incursões, uma vez os próprios universos etnografados realizam seus recortes a partir de critérios e termos próprios às suas realidades.

5 Tekoa remete ao lugar em que se vive e se pode desenvolver o modo de ser-pensar-agir guarani, nhandereko, que não é algo estável ou mesmo fixo, mas construído em relação e inspirado pelos ensinamentos e comportamentos das divindades, incluindo seus desvios quando caminhavam-criavam yvyrupa ("plataforma terrestre”) (ver Ramo 2014).

6 Não podemos esquecer de mencionar as pioneiras nos estudos de gênero na Antropologia, Ruth Benedict e Margaret Mead. Entretanto, não há muitas reflexões sobre mulheres indígenas na política. É importante ressaltar também que xs autorxs dos estudos clássicos acerca dos Guarani se inserem dentro das tendências teóricas e metodológicas de um secular projeto androcêntrico de Ciência, que não exclui a Antropologia (ver Overing 1986 e Corrêa 2003). P. Clastres, no entanto, realiza um importante estudo de gênero em $O$ arco e 0 cesto (2003 [1966]), ainda que marcado pelo viés masculino de sua época. Ao final do Infortúnio do guerreiro selvagem, o autor também traz questões interessantíssimas sobre gênero, como por exemplo, a ideia das mulheres, nessas sociedades contra o estado e para a guerra, como seres-para-a-vida e, dos homens, enquanto seres-para-a-guerra, como seres-para-a-morte, ressaltando "uma proximidade essencial entre masculinidade e morte" e "imediata entre vida e feminidade", reconhecendo a sua necessária imbricação e a intencionalidade política de ambos (2011 [1977]: 286-287). Sobre o persistente androcentrismo nas descrições e análises de formas políticas nas Américas, que seguem em busca de chefes, xamãs e outras lideranças masculinas, ver Perrone-Moisés (2015) e Aranha (2018). 
das diferentes disposições coletivas de produção e proteção da ( $\mathrm{r}$ )existência nesta terra, vem também do fato $\mathrm{d} @ s$ Guarani (assim como outros povos ameríndios) viverem atualmente um contexto cada vez maior de valorização e protagonismo de jovens mulheres ${ }^{7}$, de abertura e conquista de espaços de fala e atuação política no âmbito da "comunidade" - isto é, para além do grupo de parentesco nuclear - e, em alguns casos, "para fora" dela, em eventos a um só tempo diplomáticos e de resistência xamânica contra o Estado, antes majoritariamente ocupados ou protagonizados por figuras masculinas ${ }^{9}$ e/ou mais velhas e experientes ${ }^{10}$. Não se trata, contudo, de esgotar um tema, e sim de levantar questões mais que pretender resolvê-las embora não deixe de apontar algumas possibilidades -, de partir de alguns aspectos das relações que @s Guarani desenvolvem entre linguagem, ética-estética, gênero e poder que possam contribuir nessa tarefa de repensar e ampliar nossas próprias concepções (e suas limitações) de polític@, linguagem, poder e gênero, no contraste mesmo com a filosofia mbya.

\section{A inspiração da palavra-nome-espírito-caminho (-nhe'ế $\left.\hat{e}^{11}\right)$}

éNhanderu mesmo que diz que você vai nesta terra para fazer essas coisas, proteger sua comunidade e seus parentes [...] Nhanderu marca cada um, qual a função que vai ter nesta terra. (Para Poty ${ }^{12}$, T.I. Tenonde Porã [SP] 2015)

\footnotetext{
7 E tem relação direta com um contexto político que reforça a emergência de ações políticas dos feminismos jurua (não-indígenas), cada vez mais requeridas pelas agências de financiamento das organizações não-governamentais (ONGs) que atuam entre populações indígenas na América Latina e que, por sua vez, acaba afetando a dinâmica interna das aldeias ainda que, muitas vezes, acabe também contribuindo ou estimulando um maior empoderamento das kunhãgue e dos jovens (pyaukue), seja pelo esforço em conceder-lhes mais espaços dentro dos projetos culturais e socioambientais, na política comunitária e-ou no quadro de empregos assalariados.
}

8 A grande maioria das palavras utilizadas entre aspas ou itálico que fazem referência direta à perspectiva guarani sobre os temas aqui discutidos, são traduções guarani de como entendem a sua própria maneira de se movimentar e fazer política, entre outras coisas, em português (jurua py), palavras essas distribuídas a mim em entrevistas abertas, gravadas em campo. Essas traduções dependem de cada pessoa e do contexto enunciativo em questão e, muitas vezes, tomam o sentido de um ato político. Quando não estou me referindo especificamente aos Guarani ou a seu modo de pensar e agir, o uso desses recursos pode remeter à literatura especializada e a conceitos ou termos já consagrados.

9 Seja por serem eles que circulavam mais entre as aldeias e falavam o idioma estrangeiro, se relacionando mais abertamente com a sociedade envolvente, seja pelo motivo, geralmente silenciado, da preocupação coletiva com a violência jurua contra as mulheres.

10 Pelo prestígio adquirido em controlar os saberes-poderes xamânicos (ver Aranha 2018).

11 Este princípio agentivo vital, de proveniência divina, é a potência primeira de comunicação com essa esfera. O compartilhamento dessa linguagem comum é fonte primordial de saberes-poderes e capacidades de entendimento, fala e ação que se desdobram em diferentes afecções ao longo da experiência e trajetória de vida de cada pessoa. Há diferentes traduções possíveis para o termo na etnologia guarani: Macedo e Sztutman (2014), por exemplo, optam por traduzir nheế como "linguagem-afeto" apesar da clássica tradução de Cadogan (1959) por "alma-palavra”, já P. Clastres (1990 [1974]) opta por "palavra-habitante". A razão pela qual opto por utilizar o termo "espírito" no lugar de "alma”, deve-se ao fato de meus interlocutores mbya assim preferirem, uma vez que associam o primeiro a algo verdadeiro, de origem divina e o segundo a algo terreno, confinado a esta terra (ver Aranha 2018).

12 Para Poty é uma importante interlocutora mbya. A maioria das citações aqui apresentadas, também por uma questão políticoetnográfica, referem-se a falas de interlocutoras (em sua grande maioria professoras e-ou lideranças da "linha de frente") com as quais tive a oportunidade de aprender ao longo dos meus anos de experiência de campo, especialmente dentro da T.I. Tenonde Porã, mas não só, uma vez que o parentesco entre os Mbya se estende por toda a yvyrupa, não se restringindo a delimitações territoriais demarcadas pelos jurua. No entanto, seleciono também algumas falas masculinas, de importantes interlocutores que me auxiliaram a compreender outros tantos pontos importantes trabalhados aqui, como é caso de Karai Jekupe (educador-e-liderança) e do xeramoĩ, Karai Poty, por exemplo, sem desmerecer outr@s tant@s que muito me ensinaram ao longo dessa caminhada e não se encontram expressamente aqui citad@s. A respeito da onomástica Mbya, ver levantamento realizado por Ladeira (2007 [1992]) dos nomes-palavras-espíritos, seus respectivos gêneros, e dos possíveis casamentos ideais entre eles. 
Cada pessoa-guarani viria com um "caminho" traçado ou iluminado por Nhanderu, que seria quem "põe no caminho" ou quem o "mostra”, "ilumina” (Nhanderu omo'exakã $\tilde{a}^{13}$. Para @s Mbya, cada um nasce com certas habilidades, "independente do gênero", como traduziram para o português ${ }^{14}$, algo como um "dom" ou uma "disposição" em potencial a ser cumprida como uma "missão" aqui na terra, ou seja, capacidades-poderes (-po'aka ${ }^{15}$ ) para (se) realizar (em) algo e obter efeito. Tais capacidades devem ser desenvolvidas ou aprimoradas ao longo da experiência-caminho (tape) de vida de cada pessoa e de suas ações e relações, levando ao fortalecimento corporal-espiritual (aguyje) e podem ter relação direta com o local de origem de seu nheêe e com sua "missão" dentro do coletivo.

Karai comentou comigo diversas vezes que @s Guarani foram enviados ao mundo por Nhanderu, que já "tem uma missão para cada um", por isso devem procurar "sempre se desenvolver cada vez mais" e seguir sua missão (Karai Jekupe, T.I. Tenonde Porã [SP] 2015). Segundo o educador, “a experiência que cada um tem em alguma coisa”, suas habilidades em, por exemplo, trançar uma cesta (ajaka) ou em preparar poderosos remédios do mato (poã), "vem de Nhanderu”, pois "sem ele não fazemos nada". Kerexu, outra grande liderança mbya, também conta que "essa parte física nossa é escolhida para exercer uma função, a gente é escolhido por Nhanderu mesmo" (Kerexu Yxapyry, T.I. Morro dos Cavalos [SC] 2015). A palavra-nome-espírito (-nheê) revelada pelos Nhanderu e Nhandexy kuery ${ }^{16}$ aos xeramoĩ è̀s xejaryi ${ }^{17}$ kuery (e, eventualmente, aos próprios pais, tios e parentes muito próximos) se relaciona, assim, a essa "missão" e sabedoria $\left(\right.$ arand $\left.u^{18}\right)$ divina recebida:

a gente têm uma essência de formação, de identidade ou de uma profissão mesmo no momento em que a gente recebe o nome, porque quando a gente recebe o nome já vem com toda uma função junto, então é a partir dali que a criança começa a praticar, a ouvir, a praticar e ele mesmo se tornar [...] esse nome também é um espirito né, um espírito sagrado que vem já pronto, a gente já ganha um pacote completo aqui, e a partir daí vai ter que chegar o momento que [eu vou falar] "eu sei que é isso" né. (Idem, grifos e alterações minhas)

13 Apesar de entenderem que Nhandexy ("nossa mãe"), companheira de Nhanderu ("nosso pai"), também ilumina, @s Guarani com quem convivo, utilizaram muitas vezes a referência à sua divindade primeira (tenonde) para ensinar para mim, assim como para outros jurua, essa iluminação do caminho (tape) pelas divindades. Todos os outros seres divinos que surgiram a partir de Nhanderu Tenonde também possuem esposas, mães dos nheée e que, junto a eles, cuidam e protegem seus próprios amba ("morada"). Sobre a importância da figura de Nhandexy e da perspectiva feminina guarani, ver Benites (2018).

14 Sobre a tarefa cada vez mais urgente da Antropologia em se atentar para o "português dos índios”, ver Perrone-Moisés (2015).

15 Po'aka remete a poder, capacidade e-ou autoridade e deriva de po'a que Dooley traduz como "sorte pessoal": "na cultura antiga, a sorte era vista como sendo dom de Deus para certo indivíduo. Daí, ele poderia achar caça facilmente, acertar a caça com flecha quase sem mirar, persuadir outros com palavras aptas" (2006: 152, grifos meus).

16 Kuery corresponde a um coletivizador e, no caso em questão, corresponde às divindades.

17 Literalmente "meu avô" e "minha avó", no plural, nhaneramoĩ e nhandejaryi, em referência a sábios anciães, rezadores(as) e-ou xamãs (karai kuery), cada qual com estilos próprios (-reko) de liderança e orientação. Também podem ser chamados xamoĩ e jaryi, forma não relacional, àqueles(as) que ainda não são avós, mas possuem a capacidade xamânica de fala, canto-reza e cura maximizada e reconhecida por um coletivo.

18 Uma interlocutora me contou que a sabedoria ou crescimento espiritual ( $a r a n d u$ ), segundo ensina sua avó, envolve um aprendizado constante do saber ouvir-sentir (-endu) o dia (ara), e se baseia, principalmente, no uso do petỹgua (cachimbo) e na prática do japyxaka (escuta atenta), quando se abrem para ouvir-sentir as palavras sagradas (Para Yxapy, Tekoa Koēju 2018). Dooley, por sua vez, traduz -móarandu como o ato de "ensinar a sabedoria a alguém", "disciplinar para andar corretamente" (2006: 18). Arandu, segundo Cadogan, vem de "endu, andu = oír, percibir" e "traduce nuestro concepto de ciencia, pudiendo esta ser mala: vai, o buena: porä" (1959: 46). 
É como @s Guarani sempre dizem e o xeramoí sintetiza: “cada um tem o seu jeito de ser”, seu próprio teko (Karai Poty, T.I. Tenonde Porã [SP] 2016). Ou, como conta a xejaryi: "os xamoĩ sempre falam que quando Nhanderu manda nhandekuery para a terra, ele manda com uma missão na terra porque você vem com o dom de fazer o que você gosta e isso é Nhanderu que mandou para você" e, por isso, ela reforça: "faço o que eu gosto, eu faço o que eu tenho vontade, xepy'a py pe ["o que está dentro do meu coração ${ }^{19}$ "], dentro de mim, no meu coração, o que eu quero fazer, o que é bom para eu fazer, então isso vem do dom que Nhanderu mandou pra mim" (Kerexu, T.I. Tenonde Porã [SP] 2015, grifos e alterações minhas). Essa ideia vai de encontro ao que outro xeramoí conta: "O mesmo que você trabalhou lá em cima [...] você vai trabalhar aqui" (Augustinho apud Ramo 2014: 68, grifos meus). O que traduzem em português por "dom" teria a ver então com essa disposição da pessoa aqui na terra, com o seu próprio “jeito" (xereko, literalmente, "meu jeito", "meu costume"), que é o modo como @s Mbya se referem às maneiras com que cada um age, sua singularidade: "eu tenho o meu próprio sistema [...] que é a minha função" (Kerexu Yxapyry, T.I. Morro dos Cavalos [SC] 2015, grifos meus).

Ara Rete também lembra que sua avó sempre dizia que “'as pessoas são mundos diferentes', por isso é importante saber ouvir", para aprender a viver entre mundos (Benites 2018: V, grifos meus). Por isso, "não basta só querer" ser, por exemplo, uma "liderança”" (-uvixa), ou mesmo saber fazer determinado trançado, é algo que "vem de dentro" e que se vai desenvolvendo ao longo da sua caminhada (-guata) pelo mundo, acompanhando e "aprendendo junto" aos parentes (-retarã kuery, nhandekuery) (Para Poty, T.I. Tenonde Porã [SP] 2015). Uma vez que, complementa Karai, "cada nome tem um modo de ver" (Karai Poty apud Macedo 2010: 230, grifos meus). Com as palavras-nomes-espíritos vêm todo um corpus de saberes-poderes referentes às suas moradas divinas (amba) de origem que correspondem a "costumes" e "trabalhos" específicos que já realizavam nos amba das divindades a que são vinculadas e as habilitam a realizá-los também em yvyrupa. Alguns desses "trabalhos" para os quais foram enviados em "missão" seriam prerrogativas de certas moradas, correspondendo a filiações e disposições diversas, assim como ocorre com os pais e mães dos nhễe kuery que ao serem nomeados-engendrados por Nhanderu Tenonde são diferenciados pelos elementos ou objetos que são designados a guardar-cuidar e fazer agir neste (e noutro) mundo.

Cadogan (1959) transcreve as belas palavras divinas (nhẽe porã) enunciadas por seus interlocutores guarani acerca de sua própria origem, que ilustram esse processo de desdobramento que se inicia com o "desabrochar" (-mbojera $\left.{ }^{20}\right)$ de Nhanderu Tenonde que desdobra a si mesmo e, a partir de si, gera as demais divindades. Dessas últimas desdobram-se o que Cadogan denomina de "lugartenientes", seus filhos e filhas, espécies de auxiliares, algo como seus xondaro e suas xondaria (guardiães-guerreir@s).

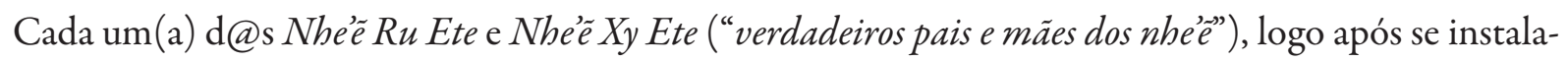
rem nos lugares em que Nhanderu Tenonde criou as "palmeiras eternas", recebeu do demiurgo a tarefa de cuidar de um elemento: Karai, por intermédio de seus filhos e filhas, "los Karai valerosos” (“nde ra’y

19 Em mbya, -py'a pode significar tanto fígado, como coração ou estômago. É a fonte das emoções e em função predicativa pode significar também “pensar: xepy'a aikovy mba’emo anhotỹi aguã fico pensando em plantar alguma coisinha” (Dooley 2006: 160).

20 Segundo Pierri (2013), ombojera remete a um processo de transformação e não apenas um ato de criação, como ocorre no caso da transformação do botão em flor. Já Cadogan traduz o termo “ñembojera” como “crearse a sí mismo; Nande Jarýi a’e ae oñembojera Nuestra Abuela se creó a si misma” (1992: 129). Dooley traduz o termo -jera por “desamarrar-se” e -mbojera como “fazer o espírito de (alguém) viver de novo, depois de morrer" ou "criar (algo ou alguém) do nada, ou transformar em outra coisa" (2006: 67-68). 
Karai Py’aguachu”), "Señores dueños de las llamas" ("Karai Tataendy ja”), fará vigiar as sagradas "hileras de llamas inasequibles" ("tataendy ñeỹchyrõ re") a partir das quais o próprio Nhanderu se inspira; Jakaira fará com que seus filhos e filhas, "los Jakaira de corazón grande” ("nde ra’y Jakaira Py’aguachu”), vigiem a "fuente de la neblina que engendra las palabras inspiradas" ("tatachina ñe'engatu rapyta rã $i$ $r e$ ") e, por isso, serão chamados "dueños de la neblina de las palabras inspiradas" ("tata-china ñéengatu já rã i”); já Tupã irá se encarregar do "extenso mar en su totalidad", enviando "repetidamente a la morada terrenal” através de seus filhos e filhas, "los Tupã de corazón grande" ("nde ra’y Tupã reta py'aguachu”), "aquello que refresca” (“mba’e ñemboro'y”), isto é, a "moderación”, que deve se alojar no centro do seu coração ("py’a mbyte py") (1959: 33, 31, 32, grifos meus). Segundo narra um sábio xeramoĩ, é do seu próprio corpo-espírito que Nhanderu engendra sua companheira, dando origem às kunhãgue:

Quando Nhanderu se gerou, ele estava sozinho, ele não tinha pai nem mãe. Quando ele veio neste mundo, ele tinha um popygua e veio através dele, vagando pelo mar. Mesmo sendo um deus, ele também passou dificuldade porque só vivia através do popygua e do Kuaray jexaka, que é o reflexo do Sol. Ele conseguia a força só através desses dois. Como ele vivia sozinho, pensou em fazer uma companheira pra ele. Foi assim que gerou a companheira dele! Mas, mesmo sendo ele Nhanderu, ela não queria ser mulher, não queria se levantar. Meus avôs diziam que, quando ele fez a mulher, ela não tinh a força pra se levantar, caía. Então, ele tirou um osso da parte da costela, pra fazer a mulher ficar forte, pra levantar. Tirou aquele pedacinho e colocou na mulher, na companheira dele, pra viverem juntos até hoje. Nhanderu fez a companheira pra ele de seu osso ${ }^{21}$. (Vera Mirim, Tekoa Xapukai/ Brakui, RJ. In: Guata Porã 2015: 10, grifos meus)

É por isso que "na Opy, é a mulher que pode dar mais força para os homens. Nhanderu mandou as mulheres na Terra e, para elas, é mais fácil rezar para Nhanderu. Sendo mulher, Nhanderu mesmo vai ensinar mais" (Ibidem: 89, grifos meus). Pierri também registra a criação das mulheres a partir do corpo de Nhanderu em uma versão da narrativa que conta a respeito da origem dos homens (avakue) e mulheres (kunhãgue), indígenas e não indígenas e das relações homossexuais: "no início do mundo mesmo, eram só homens, e da batata da sua perna Nhanderu criou a mulher. Por isso é mais fácil para as mulheres se aprofundarem na opy [casa de rezas] pois seu corpo éfeito do corpo de Nhanderu" (2013: 83, grifos meus). $\mathrm{Na}$ versão de outro grande xeramoí, interlocutor de Ramo, Nhanderu Pa-Pa errou quando foi enviado por Nhanderu Tenonde para a Terra, pois trouxe só homens, criando as mulheres também a partir de si:

Quando Nhanderu Pa-Pa terminou de trabalhar na Terra, deixou os homens para continuar trabalhando [...] Só que naquela época os homens dormiam todos juntos [...] Aí um desses homens engravidou. Nhanderu Pa-Pa voltou pro amba e contou pra Nhanderu o que tinha acontecido, perguntando o que deveria fazer. Nhanderu Tenonde falou: "Agora você que tem que saber, pra criar”. Aí Nhanderu Pa-Pa tirou duas costelas de si mesmo para criar a mulher. É por isso que nos homens, todos, falta um pedacinho de costela, é só procurar; já na mulher não falta [...] E por isso, a mulher é mais sagrada do que o homem (Ramo 2014: 33, grifos meus)

21 A primeira mulher foi gerada a partir de uma parte do corpo-espírito de Nhanderu Tenonde, de seu próprio osso, e talvez seja por isso que recebam mais ensinamentos divinos e constantemente sejam ensinadas e, por vezes repreendidas, a errar menos e preservar mais seus corpos-espiritos, que detêm a capacidade de gerar e trazer à vida novos parentes, fazendo a mediação entre corpos-mundos-territórios, celestes e terrestres e atuando como peças centrais na produção-proteção e desenvolvimento do coletivo. 
Ladeira (2007 [1992]) lembra também que a maioria dos tekoa hoje existentes no litoral foram fundados tendo à frente uma liderança feminina (ver Ciccarone 2001). Essas kunhã karai (xamã-rezadora), cujos nhe'ê, geralmente, seriam provenientes da região de nhanderenondere (local onde Kuaray, o Sol, nasce), são figuras-chave tanto na definição do lugar de parada e permanência do grupo durante suas caminhadas em direção à terra sem mal (yvy marã é̃) como na escolha do espaço em que irá ser construído e produzido o tekoa. Essa disposição de seguir à frente de um coletivo, orientando e iluminando o seu caminho, como tenondegua, viria dessa inspiração da própria palavra-nome-espírito que funciona como uma espécie de "regra" recebida das divindades:

a partir do nome da pessoa ela exercia uma função, então existiu grandes líderes mulheres no passado que lideravam uma comunidade toda né, e não era uma politica imposta pelo homem, era uma lei, uma regra recebida diretamente de Nhanderu, então todos que estavam nessa função, recebia o chamado [...] [como a kunhã karai] Tataxĩ, que fez a caminhada dela desde o Paraguai atéo Espirito Santo, e ela passou pelo Morro dos Cavalos [...] ela liderou em nome de Nhanderu, eu já sou mais [da parte] política mesmo. (Kerexu Yxapyry, T.I. Morro dos Cavalos [SC] 2015, grifos e alterações minhas)

É por isso que, assinala Ladeira:

$\mathrm{O}$ fato de serem os homens, em geral, os dirigentes das cerimônias religiosas, não implica que as mulheres não sejam também portadoras do dom das premonições e suscetíveis às revelações. A equivalência em termos de "graus de importância", dos papéis femininos e masculinos não é posta em dúvida no pensamento mbya. [...] A maior exposição do homem na sua função de dirigente espiritual, que exige uma performance física mais exuberante, não é mais valorizada, enquanto gênero, do que o perfil orientador (as sugestões e orientação da mulher ao próprio dirigente são sempre determinantes) e a preservação do físico feminino. (2007 [1992]: 131-2, grifos meus)

Um necessita do outro para ( $\mathrm{r}$ )existir, para se constituir como pessoa e passar pelas duras provações (-eko a'âa, -a'a $\left.\tilde{a}^{22}\right)$ no estreito caminho (tape mirî́) até yvy mara éỹ, como orienta o princípio cosmológico mbya de complementaridade (não antagonismo) dos papéis coletivos masculinos e femininos do casal e, também, nos ensina a filosofia do "Contra-Um"23 ameríndio que parte de um "dualismo em perpétuo desequilíbrio" (Lévi-Strauss 1993 [1991]), onde "tudo é dois, porque tudo é relação e dois é condição, necessária e suficiente, de relação" (Perrone-Moisés 2011: 872, grifos meus). O Um equivale aqui à imperfeição, incompletude e finitude do ser, daí sua recusa ativa, preferindo, no lugar, movimentar-se entre os polos-pêndulos, "sem jamais fixar-se num deles, o que equivaleria a resolver (abolir) a diferença pela identidade” (Ibidem: 868). P. Clastres, inspirado pelos ensinamentos de um xamã mbya escreve: "O Mal é o Um. O Bem não é o múltiplo, mas o dois, ao mesmo tempo o um e seu outro, o dois

22 O termo - áâ, de acordo com Dooley, remete tanto a "arremedar, imitar", "provar" e "medir", como a realização de "prova de coragem (entre duas pessoas)" (2006: 27). Segundo Cadogan, tanto o termo py'a ráä como teko ráä pode ser traduzido como "tentar, someter a prueba" (1992: 147; 173).

23 Ideia desenvolvida por P. Clastres no ensaio Do Um sem o múltiplo no qual discorre sobre a fala de um xamã mbya de uma aldeia paraguaia que teria lhe confessado a aversão filosófica de seu povo a tudo aquilo que se assemelhe ao Um: "As coisas em sua totalidade são uma: e para nós que não desejamos isso, elas são más" (2003 [1972]: 188). Nessa "equação metafísica" própria ao profetismo guarani, "que iguala o Mal ao Um", se esconde outra equação, de ordem política, a "recusa radical do Um como essência universal do Estado" (Ibidem: 233). 
que designa verdadeiramente os seres completos” (2003 [1974]: 191). Esse preceito mítico de complementaridade do casal "funda-se no critério de que um yvyraija e uma kunhã karai como complemento, ou vice-versa, é capaz de guiar seu grupo até yvy apy" (“extremidade do mundo") (Ladeira 2007 [1992]: 93). Os mitos de origem orientam inclusive a sua "separação" em pequenos grupos familiares, com chefia própria, a fim de que se "espalhem" pelo mundo:

Esse mundo não durará muito tempo. Meus filhos que vão estar no mundo vão ter que se separar. O mundo é muito grande. Por isso, vão se separar em, mais ou menos, três famílias, e deverão caminhar (oguata) [...] cada um com suas companheiras, cada um com suas famílias. (Karai Rataendy apud Ladeira 2007 [1992]: 142-3, grifos meus)

É importante lembrar que as etnografias clássicas sobre chefia indígena, no entanto, omitem a contribuição das mulheres nessa esfera, daí as extensas lacunas teórico-etnográficas não apenas sobre a (dis)posição das mulheres indígenas como lideranças, mas também sobre as mulheres indígenas em geral. A prolongada ênfase dos estudos etnográficos, por exemplo, na importância dos homens enquanto aqueles que falam, considerados como os únicos agentes políticos, de acordo com Passes (2004), persiste eclipsando a agência política das mulheres, apesar de diversas pesquisas atestando, justamente, o contrário ${ }^{24}$. $\mathrm{O}$ autor confirma que muito, se não a maioria, do trabalho antropológico em linguagem política coloca-a apenas em termos de "discurso formal", tomando como objeto de estudo apenas os falantes formalmente instituídos nessa arena. $\mathrm{O}$ foco das pesquisas insiste, portanto, em continuar tratando as mulheres enquanto audiência ao invés de reconhecê-las como verdadeiras agentes, ignorando dados a respeito de suas falas públicas e evidências etnográficas indicando a (r)existência de chefes femininas. O equívoco, de acordo com Passes, começa quando as pesquisas partem da suposição de que apenas a fala pública é política, presumindo também que as atividades femininas se limitariam à arena doméstica ou privada (mesmo em se tratando da análise de sociedades igualitárias), silenciando as mulheres politicamente e tornando-as politicamente silenciosas.

Há, portanto, uma relativa falta de preocupação da Antropologia na conversa cotidiana. Ao contrário, permanece aí a visão de que os homens, supostamente os únicos autorizados pelo grupo a falar publicamente, estariam de algum jeito separados do mundo de todo dia que eles falam para e pelo qual atuam. Na contramão dessas pesquisas, Passes argumenta que entre os Palikur (Pa’ikwené), povo amazônico de língua aruak, a esfera verbal cotidiana tem tanto efeito político no desenrolar da vida comunitária quanto os discursos ditos “oficiais”. O discurso político não seria somente prerrogativa de líderes ou de homens, institucionalmente autorizados ou não. A fala cotidiana, comum a todos os aldeães é, também no caso das mulheres, uma fala integralmente política, e não mais "impotente" e nem menos produtiva que a chamada "fala vazia ${ }^{25 "}$ postulada por P. Clastres. Seus interlocutores palikur, assim como os meus interlocutores guarani, consideram as mulheres politicamente iguais aos homens - o que

24 Sobre a importância da fala das mulheres, ver também Kulick (1993).

25 O "poder" do qual as palavras d@ chefe(a) ou liderança(s) encontram-se esvaziadas é de poder coercitivo, o que permitiu P. Clastres afirmar que estes personagens não dispõem de uma autoridade autoritária, regida pela lógica do comando-obediência e da coerção, própria às sociedades com Estado. É muito importante não confundir aqui "poder com coerção e autoridade com autoritarismo" (Testa 2014: 207). 
não implica sua indiferenciação - e suas ações, práticas e palavras tão importantes quanto na criação e manutenção do coletivo e seu mundo. Apesar dessas e outras evidências etnográficas, ainda não há muitas reflexões sobre mulheres indígenas na política. As análises acabam reduzindo-as a uma série de estereótipos que terminam por silenciá-las e aprisioná-las às esferas da (re)produção, sedução e / ou ao domínio doméstico, privado, negando-lhes (e eclipsando sua agência sobre)@ polític@, supostamente restrito ao universo masculino. Entretanto, é importante lembrar que pesquisas focadas unicamente em mulheres chefes ou xamãs, "longe de resolverem o problema, apenas o invertem", já que "a chefia, entre os índios, é patentemente um cargo que só pode ser assumido por um casal ${ }^{26 "}$ " (Perrone-Moisés 2015: 37). O papel das companheiras dos chefes e lideranças está, portanto:

longe de ser coadjuvante no estabelecimento do prestígio do marido, mesmo porque não existe chefe solteiro. Em muitos casos, os próprios termos nativos tratam de emparelhar chefes e suas mulheres, reconhecendo-as como "chefas", ou melhor, como parte-mulher-da liderança, mesmo que as descrições insistam em tomá-las por "mulheres de chefe". (Ibidem: 37-38, grifos meus).

Como bem destacou Ciccarone (2001), "nossas categorias e olhares não são inocentes", por isso, nossa intenção, ao menos em nossas práticas e produções etnográficas, deve ser a de sempre buscar refletir e repensar a reprodução de juízos de valor presentes no pensamento ocidental, que operam nas dicotomias e divisões entre natureza e sociedade, sujeito e objeto, masculino, feminino, público, privado, político e doméstico, ritual e cotidiano, ou mesmo entre politica e gênero, que, de algum modo, podem atéfazer algum sentido separados em nossas análises, mas não na realidade e nos valores vividos nessas e em outras socialidades. Nessas análises, por vezes, estabelecemos um corte profundo entre essas distinções sem nem ao menos tentar estancar sua ferida, ou mesmo “justificá-la”, privilegiando um lado em detrimento do outro e dificultando uma possível compreensão dessas filosofias ameríndias de ação cosmopolítica. Tais rupturas (isto ou aquilo), impregnadas de juízos e valores ocidentais, poderiam ser superadas para gerar simultaneidades (isto e aquilo, ao mesmo tempo), auxiliando no entendimento dessas lógicas outras de pensamento e ação, valorizando-as, na medida em que podem nos ensinar outros modos de ver e (r)existir.

Nas socialidades ameríndias, talvez mais do que em outras, @ polític@é feit@ na movimentação cotidiana que, por sua vez, engloba (de modo não-hierárquico) o que se convencionou denominar ritual, já que a produção-proteção das relações entre parentes envolve diferentes contextos e experiências de comunicação, a negociação constante, ritual-diária, entre sujeitos-poderes e mundos diversos, isto é, um trabalho intenso de diplomacia que, em certas ocasiões, é intensificado, mas que não cessa, ressaltando assim a necessária e inevitável imbricação e continuidade entre cotidiano-e-ritual (ao menos entre @s Guarani).

Nessas diplomacias cosmopoliticas cotidianas, fontes de conhecimento e agência, destaca Sztutman (2017), percebemos a produção mesma das relações entre gênero, geração, parentesco, xamanismo e poder. São as teorias ocidentais baseadas, principalmente, no pressuposto da dominação masculina ou desigualdade de poder entre homens e mulheres que insistem em separar ou segmentar, atribuindo-lhes seus próprios valores, o que nessas socialidades é vivido e entendido como complementos vitais, embora

26 A respeito disso, ver também Viveiros de Castro (1986) sobre o casal-chefe arawete. 
diferentes, que juntos atuam na criação e manutenção da (r)existência nessa terra. Isso não exclui que as relações construídas cotidianamente(-ritualmente) se revelem mais ou menos assimétricas (sob os parâmetros jurua), a depender de cada contexto de (enunci)ação, isto é, da rede de relações em questão, em dado mo(vi)mento. Insistimos aqui que, como a socialidade guarani é xamânica, cada pessoa pode desenvolver diferentes capacidades-poderes de ação neste mundo, de acordo com sua "missão", mas que depende também de seu "esforço" ou "interesse" e sua persistência em "saber pedir" - como traduzem meus interlocutores - e em buscar se aprimorar nessas artes de comunicação e ação cosmopolítica disponíveis a tod@s Mbya que desejem por elas se aventurar, em maior ou menor intensidade.

As diferentes disposições coletivas masculinas $e$ femininas guarani seriam então reguladas pel@s própri@s Nhêe Ru Ete e Nheẽ Xy Ete, cada casal-guardião com seu próprio amba, espaço onde vivem e guardam os diferentes domínios e elementos celestes, e as palavras-nomes-espíritos de seus filhos caçulas (nhandera'y ijapyrepyre’i), os nhêe que enviam à yvyrupa para que dela cuidem e tornem-se também seus guerreir@s-guardiães (xondaro e xondaria kuery). Cada palavra-nome-espírito possui, portanto, ao menos um pai (-ru) e uma mãe (-xy), divina-e-terrestre, que a auxilia a se fortalecer (-mbaraete), fazer seu próprio caminho e cumprir sua missão aqui na Terra. Inspirados nos casais celestes, os casais terrestres devem se fortalecer juntos-e-misturados na produção-proteção desse mundo. Entre @s Mbya (mas não só), a figura do casal ou o par feminino-e-masculino, esse movimento contínuo entre dois, seria aquilo que une movimento, ação e cooperação cosmopolítica.

\section{Sobre aprender a ouvir-sentir (n)o coração e dar voz e movimento à inspiração}

Uma série de ensinamentos e estratégias xamânicas de diplomacia cosmopolítica fazem parte do que podemos chamar de ética-estética guarani da moderação. Esta diz respeito, sobretudo, à administração e controle de seus comportamentos e afetos, isto é, de seus corpos-espíritos e de sua comunicação e movimentação pelo cosmos relacional, visando amenizar potenciais agressões de seres-poderes confinados à esfera terrestre. Seu aprendizado, sempre contínuo, se dá, com maior ênfase, na transição da infância para a vida adulta, incidindo no maior cuidado-controle e atenção aos próprios sentidos-percepções, à imbricada conexão entre nhéê e o corpo (-ete), às atitudes, desejos e ânimos, especialmente quando tornam-se exagerados ou excessivos, devendo evitar o trânsito desmedido entre espaços e lugares que possam abrigar alteridades perigosas ${ }^{27}$ e controlar (-jejoko) também o fluxo, cheiro e dispersão das próprias substâncias, especialmente os fluidos corporais, visando proteger e fortalecer sua própria perspectiva-humanidade e, por extensão, a de seus parentes. Isso ocorre devido ao reconhecimento geral da vulnerabilidade de todos corpos-espíritos enviados a esta terra imperfeita $\left(y v y v a i^{28}\right)$, que em momentos de passagem podem estar mais desatentos e desorientar-se facilmente face aos chamados,

27 Aqueles seres que não vemos (jaexa e’ỹ vảe) são geralmente associados aos "espíritos-donos-guardiães" (ija kuery) que cuidam de elementos, criaturas e humores terrestres e aos espectros patogênicos dos mortos, (-mbogua, ägue), que têm como "dono”, Xariã ou Anhã, inimigos dos heróis míticos e relacionados ao exagero, raiva e doenças.

28 Esta é uma dentre várias acepções do termo que, além de "ruim", "mau”, "feio", também pode denotar atitudes marcadas pelo excesso ou agressividade, o avesso do ideal de convivência entre parentes. 
olhares e encantos de outros seres-poderes ligados à yvy vai, aumentando o risco sempre potencial de sedução-captura e ao indesejado processo de troca de substâncias e perspectivas que leva à metamorfose corporal (-jepota) - em contraposição à transformação amplamente perseguida com as práticas que envolvem aguyje (maturação corporal-espiritual) e se baseiam na imitação dos comportamentos dos parentes divinos, imagens-guia para suas ações aqui na Terra -, inspirando grande cuidado e atenção aos comportamentos e interdições de cada gênero, em cada relação, e remete, em especial, a um uso estratégico e cauteloso da linguagem e de sua potência.

Nesse período de transição, quando estariam, particularmente, mais vulneráveis à comunicação e ataques predatórios de subjetividades não-humanas, por seu corpo estar se reconfigurando e sendo ao mesmo tempo acometido por apetite sexual, tanto as jovens moças (kunhãtaĩgue) como os jovens rapazes (kunumĩgue) seriam orientados pelos mais sábios e experientes, principalmente, como observei em campo, pelas mulheres mais velhas da família, "a moderar suas palavras, o consumo de alimentos" suas atitudes e os modos de se relacionarem em diferentes contextos" e entre grupos diversos, sobretudo os mais distantes (Testa 2014: 89-90, grifos meus). Daí que o constante investimento em aprimorar o cuidado-controle sobre o corpo-espírito e os sentidos, especialmente o ver-ouvir-sentir, desenvolvendo em si a capacidade-poder de cuidar-controlar asi mesm@(-jejoko kuaa), tenha uma atenção maior nessa fase. A intenção dos pais, avós e parentes mais próximos é ensiná-los a se comportar bem (-arakuaa $\left.{ }^{30}\right)$, falar com moderação e escutar com atenção, principalmente, aos mais velhos e sábios (e, por extensão, às divindades), antes de se pronunciar ou tomar qualquer iniciativa. Isso desenvolve um sentimento de muito respeito dos mais jovens (pyaukue), principalmente das mulheres - que devem observar um controle mais rígido e sistemático de seus corpos-espíritos dado seu potencial produtivo -, aos seus sábios anciães (nhaneramoĩ e nhandejaryi), evitando falar sobre aquilo que ainda não sabem ou não vivenciaram tanto, particularmente assuntos que dizem respeito à espiritualidade, e que reconhecem ainda não terem adquirido suficiente experiência e capacidade-poder de cuidar (-ereko), correndo o risco de fazer certos saberes, potentes demais, circularem indiscriminadamente. Tal sentimento, frequentemente, é traduzido para o português pelos meus interlocutores, especialmente as kunhãgue, ou em referência às suas atitudes em público, como "vergonha”. E revela também o receio desses jovens em "se exibir demasiadamente diante daqueles que sabem mais", como ressalta Testa (Ibidem: 270).

A preocupação em não se exibir demais enquanto detentor(a) de muito(s) conhecimento(s) é um comportamento considerado ideal entre @s Guarani, e a maneira correta de controlar a circulação e a concentração de saberes-poderes entre parentes. Certos saberes, principalmente aqueles considerados potentes demais, por seu amplo poder de ação, só devem ser revelados no momento correto para cada pessoa (o que depende muito de seu nome-espírito e do que observam @s mais sábi@s em seus comportamentos e atitudes diante da vida e dos outros), quando estejam de fato "preparadas" e se tor-

29 Com isso, querem, entre outras coisas, ensinar esses(as) jovens adult@s a compartilhar os alimentos, principalmente, quando estão mais escassos, desenvolvendo neles(as) a generosidade.

30 Ao comentar sobre a captura pel@s Mbya, de partes de outros seres-poderes para comporem seus corpos, Prates cita o uso dos ossos da saracura no "feitio de tornozeleiras a fim de garantir que as crianças adquiram a graça e a leveza para caminharem como esse animal" (2013: 146). Saracura em mbya é araku e o termo -arakua, uma variante de arakuaa é traduzido por Dooley como "comportar-se corretamente" (2006: 18). Já Cadogan traduz arakuaá por "entendimiento", sendo que "ara = universo e kuaá = saber", o saber do universo (1959: 46). 
nem capazes de assim compreendê-los, e, com isso, adquirir a necessária sabedoria para cuidar (-ereko kuaa), controlar e usá-los em benefício coletivo e não somente próprio. O que, por sua vez, revela-se uma poderosa estratégia de preservação desses saberes, considerados muito sagrados e, portanto, de circulação super restrita e amplamente controlada entre não-parentes. Temos aí também, um certo cuidado, principalmente entre os anciães, para não “passar” (-axa) mais palavras do que @ ouvinte é capaz de "pegar" (-jopy) e cuidar, como alerta Testa (2014). Isso ocorre, especialmente em relação aos saberes-poderes relacionados à cura e agressão, considerados mais potentes e perigosos. Por isso, os mais velhos cuidam para que não sejam transmitidos para qualquer pessoa, nem em qualquer momento de sua vida pois, como conta o xeramoĩ:

depende de uma pessoa de responsabilidade [...] tem vários jeitos de medicamento, então às vezes a pessoa pede só por pedir, só pra ver o que acontece, a pessoa não tá necessitada, só por farra, vamos dizer assim, então tudo isso eles [nhaneramoĩ e nhandejaryi] cuidam né, eles veem se a pessoa realmente está afim de fazer alguma coisa [boa], se não, não [...] têm coisas que eles só falam né, a gente faz assim, se cuida pra não acontecer isso, mas não mostra, quando ach a que a pessoa tá madura $o$ suficiente, tá entendendo o suficiente, [que] ele leva a sério, ai sim, ai que você dá. (Karai Poty, T.I. Tenonde Porã [SP] 2016, grifos e alterações minhas)

O xamanismo guarani, como dito antes, onde o que se considera por feminino é complementar e condição de existência e transformação em relação ao que se considera por masculino, configura-se assim como um processo contínuo de aprendizado, controle e aperfeiçoamento da própria percepção e de desenvolvimento do saber ouvir-sentir (-endu kuaa), ver (-exa kuaa) e sonhar (-exa ra'u kuaa) as verdadeiras e belas palavras (ayvu porã, nheẽ porã), ou como diria H. Clastres (1978 [1975]), as "palavras enfeitadas", saber cuidar delas e, por consequência, de si mesm@, de seu nheêe e do próprio corpo, e também de seu grupo. Enfatizamos aqui o saber ouvir-sentir, uma vez que a audição seria um dos sentidos mais valorizados entre@s Guarani como via de acesso aos saberes-poderes divinos e ao estado de máxima atenção e concentração (-japyxaka $\left.a^{31}\right)$, propício a essa interlocução. Tal capacidade auxilia diretamente o desenvolvimento de outra ainda mais fundamental, a de saber falar $\left(-\right.$ ayvu kua $\left.a^{32}\right)$ as belas e boas palavras inspiradas pelas divindades e que "vêm do coração", do "sentir no coração ${ }^{33}$ ". Essas capacidades-poderes de escuta e de fala podem se desenrolar ainda junto a outras habilidades importantes, diretamente relacionadas, tais como cantar (-poraei), rezar (-nhembo' $\left.e^{34}\right)$ e dançar (-jeroky) belamente, e dizem respeito, sobretudo, à proveniência divina de cada palavra-nome-espírito e seu caminho-missão aqui na Terra.

31 -Apyxa significa "ouvido", já -japyxaka é traduzido por Dooley como "escutar" (2006: 62). Pissolato traduz -japyxaka como "pôr-se em escuta atenta” (2007: 162). @s mbya de SP me traduziram como a busca por atingir um estado de total concentração na opy ou mesmo na vida, já meus interlocutores do Sul, traduzem como o ato de "meditar" ou o estado de "meditação".

32 Dooley traduz o termo -ayvu kuaa como a capacidade de esquivar-se na fala (2006: 25).

33 E "sentir no coração" algo que lhe satisfaz e alegra é fundamental para a continuidade da existência nesta terra, como aprendi convivendo com@s Guarani.

34 A palavra comumente usada para "rezar", -nhembo’e, também significa "estudar" ou "treinar-se" e vem da junção entre a partícula reflexiva nhe e o radical -mbo'e, "ensinar [lit., 'fazer falar']" (Dooley 2006: 125, 111). Meus interlocutores me traduziram como "estudar", já Testa (2014) traduz como "aprender". Desse modo, podemos entender -nhembo’e também como um fazer-se falar ou ainda, um fazer-se aprender. 
O saber ouvir-sentir passa pelo mesmo movimento de perceber-sentir as pessoas e as situações e envolve o (in)constante e duro aprendizado da sabedoria, do saber ouvir-sentir o dia (arandu). Esse sentir, consequência imediata do ouvir o coração, se realiza diretamente com o corpo-espírito - esse corpo diretamente conectado ao nome-espírito, que é meio e caminho de produção, circulação e compartilhamento de saberes, substâncias e memórias -, e é através dele que os afetos da raiva (vai) e da generosidade-amor $\left(m b o r a y v u^{35}\right)$ são intensamente trabalhados durante o canto-reza (tarova) e a dança na opy (casa de reza-canto-dança-cura), restaurando, embelezando e aperfeiçoando-o, dotando-o de saúde (-rexaĩ), leveza (-vevui), força (-mbaraete), coragem (-py'a guaxu $\left.{ }^{36}\right)$, paciência (py'a porã) e alegria $\left(-v y^{\prime} a\right)$ para enfrentar as adversidades e seguir com fé (-jerovia) na caminhada (-guata), combatendo a tristeza (-poriau), a dor e o sofrimento (-axy) desse mundo imperfeito, em que tudo se corrompe e perece. Como ressalta um karai: "tem que ouvir dentro, no fundo do coração. A gente está aqui na terra não para ficar quieto, mas para se movimentar, fazer o que eles, que nos enviaram, gostariam que a gente fizesse" (Perumi apud Ciccarone 2001: 218, grifos meus). Sobre o surgimento de Nhanderu Tenonde e yvyrupa, conta outro sábio xeramoĩ:

Nhanderu não teve pai nem mãe; nasceu por ele mesmo. Ainda sendo deus, ao existir ali, passou por dificuldades, pois não havia algo concreto onde pisar. Por isso, ele teve a necessidade de criar o mundo que hoje chamamos Yvyrupa, o Planeta Terra. Tudo era escuro e, no meio do escuro, Nhanderu desce e paira por cima do mar. Ele pensa o que éque vai fazer, por que é que ele veio. E, então, ele sabe através do coração: "vou fazer a Terra". (Karai Tataendy, Tekoa Itanhaen, SC. In: Guata Porã 2015: 9, grifos meus)

Nesse relato é possível perceber que mesmo Nhanderu passou por dificuldades em sua passagem por yvyrupa, assim como seus filhos caçulas que aqui vivem, e que sabia das coisas através do seu coração (-py’a). Essa "orientação guiada pela sensibilidade, pelo olho do coração" estaria inscrita em um código espírito-corporal, modelo de conduta e ação xamânica como narram os mitos de origem: "é do coração, como fonte e reflexo, que surgem o saber-poder dos(as) xamãs, e os elementos divinos que fundam a humanidade e a interação social" (Ciccarone 2004: 94, grifos meus). O importante é ouvir-sentir e falar com o coração: "Para [a kunhã karai] Tatati e os grandes pajés, o minimo detalhe é o mais importante de todos: as coisas do dia-a-dia, a solidariedade, o coração livre de ódio, do mal. Eles não querem convencer, falam, falam do fundo do coração" (Karai Mirĩ apud Ciccarone 2001: 218, grifos e alterações minhas). Essa "palavra tem que

35 É a forma não-relacional de -porayvu, "ter" ou "mostrar" "amor pelas pessoas", "mborayvu re peiko andem em amor" (Dooley 2006: 109; 149). Ayvu, além de remeter à fala de modo geral, pode também significar "amar, gostar de", como em "jajoayvua py jajapo porã joupe fazemos bem uns aos outros por amor uns pelos outros" e até mesmo "beijar: hova rupi oayvupa beijou-o muito, no rosto" (Ibidem: 26). $M b o$ é um prefixo causativo que junto à esta acepção de ayvu, pode ser entendido então como a ação de produzir amor em si e nos outros.

36 A tradução guarani para "coragem" é a mesma que "coração" "fígado" ou "estômago", "forte”. Por ser o centro das emoções, esses órgãos devem ser controlados de modo eficaz para se obter coragem e força para suportar a vida nesta terra e passar pelas diversas provações pelo caminho. A forma não relacional do radical -py’a guaxu, é mby'a guaxu. Para mais informações a respeito das relações entre corpo, espírito e emoções entre @s Guarani, ver Chamorro (2009). 
entrar" justamente para "ficar no coração ${ }^{37}$ ou no pensamento da outra pessoa", revela um rezador (apud Testa 2014: 151). E como lembra Yxapy, "a palavra émuito sábia, as palavras que a gente fala”, e para terem efeito, "é necessário que toque o coração das pessoas [...] para lutar eu tento fazer isso" (Para Yxapy, Tekoa Ko'ẽju [RS] 2016, grifos meus). Há, no entanto, a busca por certa cautela e moderação - aspecto central do xamanismo mbya -, em relação a seu uso, uma vez que elas devem partir sempre de uma boa e verdadeira inspiração para serem, de fato, eficazes, capazes de provocar movimento:

falo somente o necessário [...] [as palavras] tem que ser verdadeiras [...] tem que ter uma inspiração para falar [...] até mesmo para falar coisas do dia a dia assim [...] e é um pouco mais difícil a inspiração quando você está nessa idade [mais jovem], mas tem que pedir, tem que meditar um pouco, mas tem que ser sempre com o coração. (Idem, grifos e alterações minhas)

O silêncio, como aprendi convivendo com @s Guarani, também diz muito e, por isso, é importante aprender a ouvir-sentir as pessoas e as situações para alcançar arandu. Elxs lidam de maneira diferente com as palavras, sendo ensinad@s desde pequen@s a não falarà toa (-ayvu rive), só mesmo quando se sentem inspirad@s, o que envolve um intenso cuidado-controle sobre o corpo-espírito que também pode revelar um grande poder de movimentação cosmopolítica. A moderação na fala é algo então muito valorizado, sendo@s jovens sempre orientad@s a falar comedidamente, principalmente quando na presença d@s mais velh@s, que possuem “a prerrogativa das palavras abundantes”, como bem assinala Testa (2014).

A fala das mulheres, por sinal, é muito prestigiada, tanto no âmbito da família extensa, como em reuniões coletivas gerais da "comunidade". Suas falas, especialmente das mais velhas, são entendidas como "mais coerentes", segundo meus interlocutores, por conta de sua capacidade acentuada de "ouvir" e de "pensar bem" antes de se pronunciar, principalmente para além do núcleo familiar, enquanto os avakue já teriam "mais facilidade em falar" e "sair para fora" do grupo e "ter mais contato" com os jurua kuery. Sua "cautela", como traduziram para o português, diante das situações adversas e o maior cuidado-controle que têm de seu próprio comportamento, tanto em suas falas quanto em suas posturas e atitudes, é algo muito admirado e valorizado por tod@s. Há aí, até mesmo entre alguns interlocutores, a percepção de que as mulheres seriam pessoas "mais preocupadas com o coletivo", por serem "muito protetoras, sempre pensam no coletivo" (mesmo que entendam também que muitos deles, especialmente os mais velhos, também se preocupam e auxiliam no cuidado-proteção coletivo), o que se reflete na "delicadeza" de suas ações, "até nas palavras", tendo atitudes, geralmente, "bem mais cautelosas e calmas", ressalta Karai Jekupe (T.I. Tenonde Porã [SP] 2015).

Karai, por exemplo, considera que "a voz da mulher é bem mais ativa do que a do homem, ela impõe mais respeito" por ser mais "tranquila" e "sossegada no seu canto" e quando fala, "pensa antes" e "fala a coisa certa e pouco"38, "o homem já é mais bruto" e, dependendo da situação, "quer sempre falar mais

37 O coração, entre os povos amazônicos, seria o "centro a partir do qual os pensamentos são impulsionados, alcançando todos os órgãos e permitindo que uma pessoa aja sobre o mundo em interação com outros", assim tanto a produção de comida, como de "objetos, palavras, música, cheiros e crianças" seriam "manifestações da boa circulação dos pensamentos de uma pessoa" (Belaunde 2006: 211). Entre @s Mbya, -py’a também remete ao ato de "pensar” e tem relação direta com o saber: sabe-se, através do coração, do ouvir-sentir (n)o coração (ver Dooley 2006).

38 Entendo que, nessa fala, Karai está se referindo às falas das mulheres no âmbito público, coletivo, percepção esta, compartilhada também por outr@s interlocutorxs. 
alto", ou "age sem pensar" muito, já uma "uma liderança feminina sempre vai tentar acalmar os ânimos" de modo que as conversas não passem "do bom senso para outra coisa”, sendo aí que, de alguma maneira, a seu ver, que "entra a questão do equilíbrio" entre os gêneros (Idem, grifos meus). As mulheres "mais jovens", no entanto, teriam um pouco mais de "vergonha" (possível tradução guarani para respeito) de falar nas reuniões coletivas, o que pode ocorrer, como comentaram, pela "insegurança" que sentem de ainda não "saberem muito" sobre os temas discutidos ou por sentirem que não têm "nada para contribuir", e que sua fala-ação não será "boa" o bastante, já que ainda "estão aprendendo". Ainda assim, algumas delas "falam quando sentem que devem" e têm algo a contribuir, "ajudando muito na discussão". De modo geral, isso reflete a postura ética-estética guarani, de respeito geracional, onde os mais jovens são ensinados a primeiro aprender a ouvir-sentir as palavras-conselhos (-mongueta $\left.{ }^{39}\right) \mathrm{d} @ s$ mais sábi@s, para depois, se sentirem no coração, se pronunciar. Nessas reuniões, @s mais jovens participam mais para "acompanhar" seus parentes e as discussões e aprender com elxs, que propriamente expressarem suas opiniões, ainda em formação. As mulheres mais velhas, geralmente sábias rezadoras, no entanto, fazem maior uso da palavra nessas reuniões e outras ocasiões, dedicando-se, muitas vezes, mais que os homens a orientar as discussões coletivas, o que manifesta sua maior confiança e disposição na distribuição das palavras verdadeiras, por conta também de sua experiência-caminho de vida e trajetória de aprendizado pelos ensinamentos $\mathrm{d} @ \mathrm{~s}$ antig@s, adquirindo grande prestígio e respeito coletivo.

Enquanto grandes observadoras dos comportamentos alheios e seus excessos, as kunhãgue seriam mestras nessa arte de perceber-ouvir-sentir as pessoas e as situações e, talvez, por isso, façam maior uso de críticas a esse respeito, expondo muitas vezes, publicamente, os conflitos entre parentes e as contradições entre suas condutas e discursos, seja através da ironia, do riso ou do deboche, sem, no entanto, deixar de lado o tom jocoso guarani (ver Ciccarone 2001). Isso, por sua vez, pode funcionar, na prática, como um meio de cuidado-controle e produção-proteção do corpo-espírito familiar e, muitas vezes, para além dele, não se restringindo às kunhãgue. Nessa dinâmica de circulação de críticas-conselhos, há aquela dimensão ética-estética operando e que, como sugere Ciccarone (2001), parte de um conjunto de instruções e convenções a respeito da vida coletiva geridos, principalmente, por suas sábias anciãs - mas não só por elas -, que tomam a frente nesse processo, buscando constantemente desencadear momentos de reflexividade entre os seus, agindo como verdadeiras guardiãs dos modos sábios de viver, pensar e agir guarani.

\section{Da potência das palavras enquanto caminhos para o movimento}

Falar caminhando no meio da opy, ou mesmo em outro local em que estejam reunid@s, por vezes segurando nas mãos um petỹgua, é um costume guarani também muito valorizado. Nessas ocasiões, é possível perceber a dinâmica da fala não-impositiva, que conversa, aconselha e adverte, mas não se sobrepõe às demais, onde tod@s, idealmente, têm direito à fala e a utilizam se sentirem no coração a

39 -Mongeta é traduzido por Dooley como "admoestar, aconselhar", -nhemongeta como "salmodiar, cantar monotonamente" e nhomongeta como "aconselharem-se uns aos outros" (2006: 116). Interessante notar a correspondência entre aconselhar e cantar, confirmando a importância e continuidade dessas modalidades de fala e sua relação com o corpo entre @s Mbya. 
necessidade de compartilhar, visto que, como viemos argumentando, há uma relação direta entre a palavra (falada, rezada, cantada ou dançada), a inspiração divina e a produção de movimento e ação. Essa palavra inspirada que pode se expressar através da fala, do canto, da reza, aliar-se à dança e ser convertida em cura, é resultado de uma relação de aprendizado e escuta atenta estabelecida com a esfera divina, devendo ser feita circular entre parentes, de maneira controlada e eficiente, traduzindo-se em ações.

Os conselhos (-mongueta), orientações e ensinamentos que as lideranças (-uvixa kuery), principalmente @s nhaneramoĩ e nhandejaryi, distribuem devem ser capazes de "tocar o coração" dos retarã kuery e inspirar "confiança" (-jerovia), estabelecendo uma relação de cuidado e proteção. A conversa que aconselha-adverte seria, portanto, a maneira correta de transmissão e circulação de saberes-poderes entre parentes (celestes e terrestres) e remete ao aprender conversando, ficando junto, como traduzem muit@s Mbya. Alguns interlocutores associam o ato de fazer circular as palavras-ensinamentos divinos entre os seus, ao ato de ensinar que nomeiam, nhemongueta:

a não interrupção da sequência nhemboe (aprender, estudar, refletir) e nhemongueta (ensinar, aconselhar) é fundamental para a manutenção desse sistema. [...] os Guarani têm a consciência de que aprender é um ato espontâneo e de que não se pode obrigar ninguém a receber os ensinamentos divinos. A disposição e o empenho já são característicos de cada portador de uma alma. (Ladeira, 2008 [2001]: 33, grifos meus)

$\mathrm{O}$ "dom da palavra” ${ }^{40}$, inspirado pelas capacidades-poderes adquiridas na relação que se estabelece com a esfera divina, entretanto, pode converter-se em uma forma exagerada de controle, por vezes, excessiva, das (moviment)ações e comportamentos de parentes e agregados, dentro de um coletivo. Seu uso negativo, para convencer ou influenciar alguém a realizar algo que não necessariamente produzirá boas disposições coletivas, pode até mesmo levar à interrupção desse fluxo de saberes e circulação de uma série de doenças e infortúnios diversos. E se as boas e verdadeiras palavras funcionam como conselhos (mesmo os mais duros) e curam como remédios, comportamentos, atitudes e mesmo palavras exageradas, maldosas, carregadas de estados e humores excessivos, sem boas intenções de ajudar-curar, são vazias de sentido, pois soam como agressão e agem como feitiço (-paje, mbảevyky) ${ }^{41}$, podendo desencadear inúmeros conflitos e enfermidades. Mesmo a ética-estética da moderação operando como ideal, no controle dos comportamentos e na circulação de palavras entre parentes e outros seres-pode-

40 Conversando em campo sobre esse "dom" da palavra, uma reconhecida liderança depois de refletir um tempo sobre o assunto acabou me traduzindo como ayvu reno’ã, complementando com a explicação de que são "aqueles[as] que sustentam a palavra". Dooley traduz o radical -enoáa tanto por "levantar algo enquanto levanta a si mesmo" quanto por "levantar (outra pessoa junto consigo, uma parte do próprio corpo, ou o corpo inteiro, etc.): xepo re ava ojopy vy xererenóa o homem pegou na minha mão e me levantou (junto consigo)" (2006: 3, 36).

41 A questão da feitiçaria (mba’evyky), de "brincar" com a vida dos outros, é um grande motor de acusações, vinganças e doenças entre parentes e outros grupos distantes, por isso, muit@s Guarani preferem se mudar para outro lugar a depender da situação ou, que a pessoa acusada, quando reconhecida como tal pelo coletivo, assim o faça. Para evitá-las, @s xeramoĩ e xejaryi preferem não revelar a autoria das agressões que curam, na tentativa de apaziguar e conciliar, não gerando mais enfermidades. A figura d@ feiticeir@, imba’evykyva’e, remeteria, segundo Dooley, à do "mexeriqueiro: ka’i ma imbáevyky raxa va’e o macaco é mexeriqueiro demais" (2006: 105). É interessante notar essa associação entre mexerico ou fofoca, feitiço e feiticeir@. 
res, também podem ocorrer excessos e descontrole na fala, como a "fofoca" ‘2 (ayvuxe rei), por exemplo. Ela geralmente circula mais livremente entre jovens e crianças (kyrĩgue), que não aprenderam ainda totalmente a controlar o fluxo da fala, podendo mais facilmente cometer excessos, além de terem um trânsito mais livre entre os núcleos familiares e mesmo dentro da própria aldeia, ainda mais com o ambiente de socialização que a Escola acaba trazendo.

Esses exageros na fala, no entanto, não se restringem apenas a eles ou às mulheres, como muitos trabalhos insistem em comentar. Falas desmedidas, é importante lembrar, circulam também e, ao mesmo tempo, entre os homens, pois eles assim como outros seres-poderes podem também descontrolar-se, cometer excessos e, nesse caso, falar demais. Essa circulação de falas vazias - em contraposição à expectativa de uma fala branda ${ }^{43}$, moderada, bonita-verdadeira -, que carregam a intenção de ferir, vingar ou expressar sentimentos, emoções e humores excessivos e perigosos como a raiva (-poxy) ou o ciúme ( $a k \tilde{a}$ $\left.t e^{\prime} \tilde{y}\right)^{44}$, seja entre as mulheres, crianças, jovens ou entre os homens, pode causar inúmeros problemas internos ${ }^{45}$, que os mais velhos, especialmente, as xejaryi observam e buscam evitar, tentando inverter seu potencial predatório para a produção, sempre provisória, de boas disposições entre parentes, mas nem sempre obtêm êxito. Contudo, reduzir a intencionalidade política das mulheres apenas à fofoca, essas falas desmedidas, ou à dimensão doméstica e privada, como ocorre em muitas etnografias, acaba empobrecendo a análise, especialmente no que diz respeito à sua agência, principalmente quando nos damos conta de toda a potência que esses aspectos d@ polític@ têm no fazer e desfazer pessoas e coletivos, gerando movimento.

A fala é, portanto, um elemento central na vida social guarani uma vez que permite a comunicação entre os diferentes seres do cosmos, o desenvolvimento de sua capacidade relacional e diversas possibilidades de mobilização e potencialização de relações, saberes-poderes e prestígio. O bom-correto-verdadeiro (porã) uso da palavra envolve um aprendizado contínuo e cauteloso, pois "saber falar" (-ayvu kuaa), como insistem @s Mbya, é saber ir além da capacidade oratória e "fazer o que fala", senão a palavra é vazia, sem sentido, “à toa” (-ayvu rive). Isso é importante para a produção e promoção do amor-generosidade-reciprocidade (mborayvu) entre parentes. A sabedoria refletida na fala serve para produzir resultados, pois falar bonito é falar com eficácia, produzir movimentação no interior dos co-

42 Meus interlocutores traduzem "fofoca" em português, também como "falatório". De acordo com Dooley, tanto ayvukue, ayvuxe e ayvu reko podem ser traduzidos como "conversa fiada", "fofoca: xeayvuxe rei vy e’ỹ xeayvu não estou falando fofoca" (2006: 25-6). Ayvuxe, no entanto, significa também a simples vontade de falar: xeayvuxe ("eu quero falar"). Para dar ênfase à dimensão excessiva e desmedida da "fofoca", optamos por usar ayvuxe rei (rei, em função adverbial, significa "de maneira errada, má" [Ibidem: 167]).

43 Agradeço à Aline Crespe por ter me chamado atenção para esse aspecto da fala, "fria", segundo os Kaiowá e sua contraposição a uma fala forte, "quente" (-aku). Para mais detalhes sobre como estado quente, geralmente relacionado ao sangue (-uguy), potente agenciador da transformação por estar associado à águe e ao corpo pesado, quente, especialmente o menstrual, devendo ser devidamente resfriado (mboróy) através de diversos procedimentos xamânicos, ver Prates (2013) e Seraguza (2013). Como registrado por Cadogan, aquilo que refresca ("mbáe ñemboro'y"), a moderação, associada aos Tupã kuery, é algo que deve se alojar no centro do coração ("py’a mbyte py") (1959: 32, grifos e traduções minhas), ressaltando, mais uma vez, a importância da conexão entre palavra-nome-espírito, coração e a ética-estética da moderação.

44 Sentimentos esses veementemente repelidos uma vez que geram comportamentos e estados excessivos sendo, por isso mesmo, passíveis de crítica e diretamente relacionados à "noção de corpo pesado, quente/akú" (Prates, 2013: 181). Há aqui, portanto, uma forte relação entre estados afetivos, corpo e transformação, daí a importância de se proteger os sentidos, sobretudo a audição e a visão.

45 A dimensão efetiva que a "fofoca" ocupa como um importante instrumento de instabilidade cosmopolítica na vida cotidiana, se levamos a sério o quanto a fala produz, podendo incitar más disposições, humores perigosos e retaliações por sua potência agressora, deve ser mais etnografada. Para uma discussão sobre a dimensão política da "fofoca" e da feitiçaria no Xingu, ver Vanzolini (2015). 
letivos e para além deles. A força e o poder que a palavra inspirada tem de "questionar", "enfrentar" - como traduzem meus interlocutores -, mobilizando pessoas e relações, é uma característica amplamente apreciada e necessária no saber-fazer(-se) polític@ mbya, justamente pelo seu grande potencial de gerar (-mbojera) a força e eficácia que anuncia, mesmo que em escala menor ou menos potente que as palavras dos deuses. Os atos de falar são tidos então como atos de fazer, por isso, o cuidado e a moderação que se deve aprender a ter ao emitir as palavras, pois estas carregam a capacidade de gerar aquilo que enunciam, daí a sua potência para o "bem" e o "mal". Toda fala pode assim, atuar tanto na produção como na dissolução de coletivos e relações, pois a palavra, quando eficaz, é a própria ação em si mesma. Daí a eficácia perseguida em cada fala, seja ela "boa" ou "má" ${ }^{46}$, verdadeira ou vazia.

\section{Algumas considerações finais}

A partir do que foi dito até aqui, a respeito da agencialidade das palavras-nomes-corpos-espíritos, é possível entender a ênfase guarani - e talvez em toda parte - em sua importância e seu valor na produção e proteção do mundo, que parte de uma ética-estética que busca incessantemente intensificar a potência dessa palavra inspirada que faz fazer e sua capacidade em traduzir sua eficácia em boas ações e disposições entre parentes, mobilizando uma série de sujeitos e relações. Como ressaltamos ao longo deste ensaio, a disposição cosmopolítica de cada pessoa estaria mais bem relacionada à sua palavra-nome-espírito-caminho e experiência-missão neste mundo do que propriamente ou, necessariamente, a seu gênero ${ }^{47}$. O ideal de maturação corporal-espiritual (-aguyje) seria o mesmo para tod@s: ênfase na moderação e no cuidado-controle (-jejoko) dos excessos possíveis das palavras-corpos-espíritos e seus afetos em qualquer ação e relação, e movimentação pelo cosmos. O que faz necessário todo um esforço coletivo de diplomacia cosmopolítica, com vistas à produção e promoção da generosidade-reciprocidade (mborayvu) entre @s retarã kuery aqui na Terra e de um espaço bom, belo, alegre e saudável para se viver bem (teko porã), seguindo os ensinamentos das divindades. O bom e correto uso da palavra divina posta em movimento, que as falas-cantos-rezas-danças-curas d@s sábi@s xamãs (karai kuery) fazem circular pela Terra, envolve todo um processo de amadurecimento da conexão e do controle entre palavra-corpo-espírito-caminho, um saber se comportar corretamente (-arakuaa) que implica um investimento intenso nesse duro aprendizado e, também, muita disciplina e concentração (-japyxaka).

Para caminhar bem (oguata porã) em sua missão por yvyrupa, lembra Para Yxapy (que contêm emsi muit@soutr@s), é preciso aprender não só a ouvir-sentir, mas a pensar e falar com o coração, construindo essa sabedoria de ouvir-sentir o dia (arandu) sempre em relação, a partir de seu próprio caminho. Como observa Montardo, @s Guarani falam que fazem seu ritual cotidiano para ouvir os deuses e viver conforme o que ouvem, para não esquecer e, por isso, cantam e dançam para lembrar e cele-

46 Entre @s Mbya, a diferença entre alguma coisa "boa" ou "má" reside justamente nos efeitos que tal ação ou relação causa em seus corpos-espíritos e de seus parentes (ver Macedo 2013).

47 O que também não quer dizer que cada gênero não seja ensinado ou mesmo estimulado a investir com maior ou menor intensidade em certas disposições, no cuidado-proteção entre parentes, se especializando mais em certas atividades - o que também não exclui seu conhecimento sobre todas as demais - que outras. 
brar, deixando-se afetar, pela potência dessa relação: "O corpo que escuta, dança; o corpo que dança se torna leve, o leve é alegre e o alegre é saudável" (2002: 237, 243).

Saber vencer a tristeza é o que caracterizaria um dos principais saberes-poderes d@s karai kuery, que, para tanto, necessitam também da força e coragem d@sxondaro exondaria enviados pel@s Nhanderu e Nhandexy kuery, para atuarem junt@s nesse trabalho de mediação e composição entre mundos e planos terrestres e celestes. E, se como diz o ditado popular, quem canta seus males espanta, no caso guarani, podemos acrescentar, também, dança e caminha para o bem. Aí a alegria é a prova dos nove, anunciava Oswald de Andrade (1928), e equivale à beleza, ao bom, correto e verdadeiro (porã): "aqui, também, a beleza é um critério, inclusive no sentido de que o belo e o alegre, por si, curam (e o que cura, por certo, ébelo)" (Pimentel 2012: 193, grifos meus). Nesse longo e estreito caminho (tape mirî) para alcançar aguyje, cheio de provações (-a’ã), as belas palavras inspiradas-e-enfeitadas (nheéeporã) funcionam como instrumentos-caminhos de encontro às divindades, sejam elas traduzidas em falas iluminadas, cantos-reza ou danças, assim como o petỹgua e a fumaça (-ataxî), capazes de fortalecer (-mbaraete), curar (-monguera) e proteger como remédios (poã). São como ferramentas ou espécies de antídotos contra as tristezas e doenças desse mundo imperfeito (tekoaxy) e podem ser entendidas também enquanto disciplinas [de fabricação e controle] do corpo (Mauss 2003 [1935]), que fazem seus corpos-espíritos alegres e, por isso mesmo, saudáveis e belos.

Perrone-Moisés também já nos lembrava que, no caso ameríndio, "coisas importantes e seríssimas são feitas - é essa a desconcertante (estonteante) lição dos índios - cantando e dançando, rindo, com transbordante alegria" (2015: 103). Essas sociedades contra o Estado e para a guerra são, ao mesmo tempo e na mesma (des)medida, sociedades para a festa, confirma a etnóloga. Esse deliberado cultivo da alegria, do riso e do bom humor entre esses povos, de acordo com Perrone-Moisés, pode ser apontado ainda como uma das mais potentes "tecnologias de sobrevivência ao fim do mundo" como comentava Viveiros de Castro (Conferência Curt Nimuendaju 2013, USP). E essa especialidade ameríndia talvez seja a "mais avançada das mais avançadas das tecnologias", como canta belamente Caetano Veloso, e "surpreenderá a tod@s não por ser exótic@, mas pelo fato de poder ter sempre estado ocult@, quando terá sido o óbvio" (Um Índio 1977, alterações minhas). E não olvidemos, como cantaram e dançaram fortemente nossas guerreiras na I Marcha das Mulheres Indígenas (2019), em defesa do território: nosso corpo, nosso espírito. Lutar pelo direito a esses territórios é seguir lutando pelo direito à própria vida, pois como insistem @s Guarani, sem terra não há nhandereko. Que a força e beleza de suas palavras inspiradas abram caminho e entrem no coração jurua, e que elxs possam aprender mais com os povos indígenas sobre a potência de ouvir-sentir e falar com o coração, inspirando-se em suas lições de escuta e fala, capazes de compor e transformar nossos modos de ( $\mathrm{r}$ )existir. E que essas palavras inspiradas possam continuar guardando essa terra e iluminando novos caminhos possíveis, renovando-se a cada novo dia, $\mathrm{re}(\mathrm{x})$ istindo e adiando, com isso, o fim do mundo, como alerta Ailton Krenak, para poder sempre contar uma nova história.

Aline de Oliveira Aranha é mestra em Antropologia Social pelo PPGAS/USP e pesquisadora vinculada ao Centro de Estudos Amerindios (CEstA-USP). 


\section{REFERÊNCIAS BIBLIOGRÁFICAS}

ANDRADE, Oswald de. 1928. Manifesto Antropófago. Revista de Antropofagia. 1(1).

ARANHA, Aline de Oliveira. 2018. Inspirações sobre o fazer(-se) politic@entre os Guarani-Mbya.

Dissertação de Mestrado, Programa de Pós-graduação em Antropologia Social, Universidade de São Paulo.

BENITES, Sandra. 2018. Viver na lingua Guarani Nhandewa (mulher falando). Dissertação de Mestrado, PPGAS/Museu Nacional, Universidade Federal do Rio de Janeiro.

BELAUNDE, Luisa E. 2006. A força dos pensamentos, o fedor do sangue. Hematologia e gênero na Amazônia. Revista de Antropologia. 49(1): 205-243.

CADOGAN, León. 1959. Ayvu Rapyta: Textos míticos de los Mbyá-Guaraní del Guairá. São Paulo: FFLCH-USP.

CADOGAN, León. 1992. Diccionario Mbya-Guarani. Asunción: Fundación León Cadogan, CEADUC, CEPAG.

CHAMORRO, Graciela. 2009. Decir el cuerpo: Historia y etnografía del cuerpo en los pueblos Guaraní. Asunción: Tiempo de Historia, Fondec.

CICCARONE, Celeste. 2001. Drama e Sensibilidade: Migração, Xamanismo e Mulheres Mbya Guarani. São Paulo: Tese de doutorado, Programa de Pós-graduação em Ciências Sociais, Pontifícia Universidade Católica de São Paulo.

CICCARONE, Celeste. 2004. Drama e Sensibilidade: Migração, Xamanismo e Mulheres mbya. Revista de Indias. LXIV(230): 81-96.

CLASTRES, Hélène. 1978 [1975]. Terra sem Mal. O profetismo tupi-guarani. São Paulo: Brasiliense.

CLASTRES, Pierre. 1990 [1974]. A fala sagrada: cantos sagrados dos índios Guarani. Campinas: Papirus.

CLASTRES, Pierre. 2003 [1974]. A Sociedade contra o Estado: pesquisas de antropologia política. São Paulo: Cosac Naify.

CLASTRES, Pierre. 2011 [1980]. Arqueologia da violência: pesquisas de antropologia política. São Paulo: Cosac Naify.

CORRÊA, Mariza. 2003. Antropólogas e antropologia. Belo Horizonte: Editora da UFMG.

DOOLEY, Robert A. 2006. Léxico guarani, dialeto mbyá. Brasília: Sociedade Internacional de Linguística.

FRANCHETTO, Bruna. 1996. Mulheres Entre Os Kuikúro. Rio de Janeiro: Revista Estudos Feministas. 4(1): 35-54.

Guata Porã - Belo Caminhar. 2015. Org. Pesquisadores Guarani de Aldeias de Santa Catarina e Paraná e A. Ramo y Affonso. São Paulo: Centro de Trabalho Indigenista.

KULICK, D. 1993. Speaking as a woman: structure and gender in domestic arguments in a New Guinea village. Cultural Anthropology. 8(4): 510-41.

LADEIRA, Maria Inês. 2007 [1992]. O caminhar sob a luz. O território mbya à beira do oceano. 
São Paulo: Editora Unesp.

LADEIRA, Maria Inês. 2008 [2001]. Espaço Geográfico Guarani-Mbya: Significado, Constituição e Uso. Eduem, Edusp.

LASMAR, Cristiane. 1999. Mulheres indígenas: representações. Revista Estudos feministas. 7(1 e 2): $143-156$.

LÉVI-STRAUSS, Claude. 1993 [1991]. História de Lince. São Paulo: Companhia das Letras. MACEDO, Valéria. 2010. Nexos da diferença. Cultura e afecção em uma aldeia guarani na Serra do mar. Tese de Doutorado, Programa de Pós-Graduação em Antropologia Social, Universidade de São Paulo.

MACEDO, Valéria. 2013. De encontros nos corpos guarani. Ilha Revista de Antropologia. 15: 181-210.

MACEDO, Valéria; SZTUTMAN, Renato. 2014. A parte de que se é parte. Notas sobre individuação e divinização (a partir dos Guarani). Cadernos de Campo. 23: 287-302.

MAUSS, Marcel. 2003 [1935]. As técnicas do corpo. In: Sociologia e Antropologia. São Paulo: Cosac Naify.

MCCALLUM, Cecilia A. 2013. Nota sobre as categorias "gênero" e "sexualidade" e os povos indígenas. Cadernos Pagu. 41: 53-61.

MELlO, Flávia C. 2006. Aetchá Nhanderukuery Karai Retarã. Entre deuses e animais: Xamanismo, Parentesco e Transformação entre os Chiripá e Mbyá Guarani. Tese de Doutorado, Programa de Pós-graduação em Antropologia Social, Universidade Federal de Santa Catarina.

MONTARDO, Deise Lucy. 2002. Através do Mbaraka: Música e Xamanismo Guarani. Tese de Doutorado, Programa de Pós-Graduação em Antropologia Social, Universidade de São Paulo. OVERING, Joanna. 1986. Men Control Women? The 'Catch 22' in the analysis of gender. International Journal of Moral and Social Studies. 1(2): 135-156.

PASSES, Alan. 2004. The place of politics: powerful speech and women speakers in everyday pa'ikwené (Palikur) life. The Journal of the Royal Anthropological Institute. 10(1): 1-18.

PERRONE-MOISÉS, Beatriz. 2011. Bons chefes, maus chefes, cheföes: excertos de filosofia política ameríndia. São Paulo: Revista de Antropologia. 54/2: 857-883.

PERRONE-MOISÉS, Beatriz. 2015. Festa e guerra. Tese de Livre-Docência, Departamento de Antropologia, Universidade de São Paulo.

PIERRI, Daniel Calazans. 2013. O perecivel e o imperecivel: lógica do sensível e corporalidade no pensamento Guarani-Mbya. Dissertação de Mestrado, Programa de Pós-Graduação em Antropologia Social, Universidade de São Paulo.

PIMENTEL, Spensy K. 2012. Elementos para uma teoria politica kaiowá e guarani. Tese de Doutorado, Programa de Pós-Graduação em Antropologia Social, Universidade de São Paulo. PISSOLATO, Elizabeth. 2007. A duração da pessoa: mobilidade, parentesco e xamanismo mbyá (guarani). Tese de Doutorado, PPGAS/Museu Nacional, Universidade Federal do Rio de Janeiro. PISSOLATO, Elizabeth. 2012. "Gênero, casamento e trocas com brancos”. Pp. 98-109 in Gênero e Povos Indigenas, org. A. Sacchi e M. Gramkow. Rio de Janeiro, Brasília: Museu do Índio/GIZ. 
PRATES, Maria P. 2013. Da instabilidade e dos afetos: pacificando relações, amansando Outros. Cosmopolítica guarani-mbyá (Lago Guaíba/RS-Brasil). Tese de Doutorado, Programa de Pós-graduação em Antropologia Social, Universidade Federal do Rio Grande do Sul.

RAMO, Ana Maria. 2014. De pessoas e palavras entre os Guarani-Mbya. Niterói: Tese de Doutorado, Programa de Pós-graduação em Antropologia, Universidade Federal Fluminense.

SERAGUZA, Lauriene. 2013. Cosmos, Corpos e Mulheres Kaiowa e Guarani: de Aña à Kuña.

Dissertação de Mestrado, Programa de Pós-graduação em Antropologia, Universidade Federal da Grande Dourados.

STRATHERN, Marilyn. 2006 [1988]. O gênero da dádiva: problemas com as mulheres e problemas com a sociedade na Melanésia. Campinas: Editora da Unicamp.

STRATHERN, Marilyn. 2014 [1984]. "Sujeito ou Objeto? As mulheres e a circulação de bens de valor nas terras altas da Nova Guiné”. In O efeito etnográfico e outros ensaios. São Paulo: Cosac Naify.

SZTUTMAN, Renato. 2012. O profeta e o principal: a ação política ameríndia e seus personagens. São Paulo: Edusp.

SZTUTMAN, Renato. 2015. Diplomacias cosmopoliticas nas terras baixas sul-americanas - Exercícios de comparação etnográfica. Projeto de Auxílio à Pesquisa. São Paulo: FAPESP.

SZTUTMAN, Renato. 2017. Relatório Parcial: Diplomacias cosmopolíticas nas terras baixas sulamericanas - Exercícios de comparação etnográfica. São Paulo: FAPESP.

TESTA, Adriana. 2014. Caminhos de saberes Guarani Mbya: modos de criar, crescer e comunicar. Tese de doutorado, Programa de Pós-graduação em Antropologia Social, Universidade de São Paulo.

VANZOLINI, Marina. 2015. A flecha do ciúme: o parentesco e seu avesso segundo os Aweti do Alto Xingu. São Paulo: Terceiro Nome.

VIVEIROS DE CASTRO, Eduardo. 1986. Araweté: os deuses canibais. Rio de Janeiro: Zahar/ Anpocs.

VIVEIROS DE CASTRO, Eduardo. 2002. "Perspectivismo e multinaturalismo na América indígena”. Pp. 345-399 in A inconstância da alma selvagem e outros ensaios de antropologia. São Paulo: Cosac \& Naify. 
Resumo: Este ensaio parte de uma proposta de análise da potência da palavra-nome-espírito-caminho (nhế) entre @s Guarani Mbya e sua capacidade de inspirar e traduzir-se em movimentos e ações, passando por uma discussão da relação entre linguagem, política e gênero e pelas estratégias e cuidados, parte da ética-estética xamânica da moderação, envolvidos na produção-proteção dos corpos-espíritos, afetos e mundos guarani. É também uma tentativa de contribuir, de uma perspectiva não androcêntrica, para um entendimento possível da relação entre nheê e as diferentes disposiçôes coletivas que cada pessoa desempenha na diplomacia cosmopolítica mbya, valorizando, em especial, o protagonismo e agência cosmopolítica das kunhãgue ("mulheres") e suas inspiradoras lições de escuta e fala, que implicam um aprendizado contínuo do saber ouvir-sentir-pensar-falar-agir com o coração ( $\left.p y^{\prime} a\right)$. Essas sábias lições podem nos auxiliar na tarefa de repensar e ampliar nossas próprias concepções de polític@, linguagem, poder e gênero e, quem sabe, compor e transformar nossos modos de (r)existir.

Palavras-chave: Guarani Mbya; xamanismo; gênero; mulheres indígenas; diplomacia cosmopolítica.

\section{WITHOUT INSPIRED WORD, THERE IS NO MOVEMENT: MBYA HEARING AND SPEAKING LESSONS}

Abstract: This essay starts from a analysis proposal of the power of the word-name-spirit-path (nhe'e) among the Guarani Mbya and its capacity to inspire and translate into movements and actions, going through a discussion of the relation between language, politics and gender and by the strategies and care, part of the shamanic ethics-esthetics of moderation, involved in the production-protection of guarani spirit-bodies, affections and worlds. It is also an attempt to contribute, from a non-androcentric perspective, to a possible understanding of the relation between nhe é and the differents collectives dispositions that each person perform in mbya cosmopolitical diplomacy, valuing, specially, the protagonism and cosmopolitical agency of the kunhägue ("women") and their inspiring hearing and speaking lessons, which imply a continuous learning of hear-feel-think-speak-act with the heart ( $\left.p y^{\prime} a\right)$. These wise lessons can assist us at the task of rethink and extend our own conceptions of politic(al)s, language, power, and gender, and perhaps compose and transform our ways of (r)exist.

Keywords: Guarani Mbya; shamanism; gender; indigenous women; cosmopolitical diplomacy.

RECEBIDO: $03 / 11 / 2019$

APROVADO: $14 / 05 / 2020$ 
84 CAMPOS V21 N.1 p. 61-83 jan.jun.2020 